Kumawula, Vol. 1, No.3, Desember 2018, Hal 219- 226 DOI: http://10.24198/kumawula.v1i3. 23457

ISSN 2620-844X (online)

Tersedia online di http://jurnal.unpad.ac.id/kumawula/index

\title{
PELATIHAN DESAIN GRAFIS DAN FOTONOVELA UNTUK WARGA DESA NGEMBAL KEC. WAJAK KAB. MALANG
}

\section{GRAPHIC AND PHOTONOVELA DESIGN TRAINING FOR CITIZENS OF NGEMBAL VILLAGE, WAJAK MALANG DISTRICT}

\author{
Rini Agustina1, Dodit Suprianto ${ }^{2}$ \\ ${ }^{1}$ Program studi Sistem Informasi, Universitas Kanjuruhan Malang, \\ 2Jurusan Teknik Informatika, Politeknik Negeri Malang \\ 1riniagustina@unikama.ac.id, 2dodit.suprianto@polinema.ac.id
}

\begin{abstract}
Industry 4.0 offers remarkable technological advances and is very influential on the service of community institutions at the village level. Currently, the village has made many improvements in terms of services to the community, one of which is a service in terms of technology and information. Information from the central government must be conveyed to the public quickly because the information has an expiry period. The information conveyed will certainly be very useful for rural communities, for this reason, there is a need for rapid and appropriate socialization. The purpose of this activity is to increase the creativity of village officials and citizens in making information media. Training to create graphic designs and photography to convey information and other village activities in an effort to promote activities. Training to make graphic and photo designs becomes something that is very necessary to increase the creativity of the village leaders and the community they represent. The solution offered is to provide training assistance in graphic design and photography for the residents of Ngembal Village, Wajak District, Malang Regency.
\end{abstract}

Keywords: Training, Graphic Design, Photonovela, Corel Draw

\begin{abstract}
ABSTRAK
Industri 4.0 menawarkan kemajuan Teknologi yang luar biasa dan sangat berpengaruh terhadap pelayanan lembaga masyarakat ditingkat desa. Saat ini Desa telah melakukan banyak peningkatan dalam hal layanan kepada masyarakat, salah satunya adalah layanan dalam hal teknologi dan informasi. Informasi dari pemerintah pusat harus segera bisa tersampaikan kepada masyarakat dengan cepat karena informasi memiliki masa kadaluwarsa. Informasi yang disampaikan tentunya akan sangat berguna bagi masyarakat desa, untuk itu perlu adanya sosialisasi secara cepat dan tepat. Adapun tujuan dari kegiatan ini adalah untuk meningkatkan kreatifitas dari perangkat desa dan warga masyarakat dalam membuat media informasi. Pelatihan untuk membuat desain grafis dan fotonovela untuk menyampaikan informasi serta kegiatan desa lainnya dalam usaha untuk mempromosikan suatu kegiatan. Pelatihan untuk membuat desain grafis dan fotonovela menjadi hal yang dirasa sangat perlu untuk menigkatkan kreatifitas dari perangat desa maupun masyarakat yang mewakili. Solusi yang ditawarkan adalah memberikan Pendampingan pelatihan dalam desain grafis dan fotonovela Untuk Warga Desa Ngembal Kecamatan Wajak Kabupaten Malang.
\end{abstract}

Kata Kunci : Kata Kunci: Pelatihan, Desain Grafis, Fotonovela, Corel Draw 


\section{PENDAHULUAN}

Pada era industri 4.0 saat ini teknologi berkembang sangat pesat dan hampir telah mempengaruhi semua aspek kehidupan manusia. Era teknologi informasi ini ditandai dengan kecepatan dan kemudahan untuk mendapatkan informasi yang dibutuhkan. Perkembangan teknologi informasi dan komunikasi telah memberikan wacana dan wawasan baru bagi dunia untuk memudahkan manusia di semua sektor kebutuhan hidupnya. Mulai dari para profesional, praktisi, akademisi hingga ibu rumah tangga saat ini telah menggunakan teknologi untuk menjangkau dan memenuhi semua kebutuhan mereka, mulai dari browsing, chating, sosial media hingga berbelanja (online shopping).

Perkembangan yang terjadi juga berpengaruh pada seluruh lapisan masyarakat baik Lembaga pemerintahan, industri, Pendidikan, kesehatan, hingga unit-unit makro dan mikro perekonomian lainnya. Tidak terkecuali lembaga pelayanan masyarakat ditingkat desa. Desa saat ini telah melakukan banyak peningkatan dalam hal pelayanan kepada masyarakat, termasuk salah satunya adalah pelayanan dalam hal pemberian informasi. Informasi dari pemerintah pusat harus segera bisa diserap oleh masyarakat dengan cepat mengingat adanya tenggat waktu dan masa di setiap informasi yang disampaikan. Informasi yang diberikan tentunya akan sangat berguna bagi warga oleh karena itu perlu adanya sosialisasi secara cepat dan tepat.

Sosialisasi di desa yang belum mengenal adanya internet sedikit mengalami kelambatan dibandingkan wilayah lainnya karena media penyebaran informasi yang masih bersifat kontekstual/ tertulis. Meskipun informasi tetap tersampaikan kepada warga tetapi hal ini menjadi kendala tersendiri apabila tidak ada SDM dan media untuk menyampaikan informasi. Media yang ada saat ini masih sangat sederhana dan kurang menarik, sehingga masyarakat tidak tertarik untuk membaca informasi yang telah dipasang atau ditempelkan pada papan pengumuman. Selain keterlambatan Informasi, hasil kegiatan desa juga tidak didokumentasi dengan baik sehingga perangkat desa dan warga sendiri tidak mengetahui hasil perkembangan dari kegiatan mereka yang telah dilakukan selama ini. Warga yang telah mengikuti kegiatan seringkali menanyakan hasil dari perkembangan program yang telah mereka kerjakan, tetapi tidak mendapatkan jawaban yang tepat karena kurangnya dokumentasi kegiatan tersebut.

Menyiasati hal tersebut perangkat desa dan pimpinan mencoba melakukan kreatifitas dengan mendesain media informasi untuk menarik minat warga agar mau membaca informasi yang disampaikan, serta melakukan pendokumentasian kegiatan warga dengan lebih baik. Kegiatan ini juga dilakukan untuk menggerakkan warga agar lebih kreatif dalam usaha mandiri dibidang desain. Desain yang diinginkan selain untuk menampilkan informasi juga digunakan untuk keperluan lain seperti pembuatan pamflet lomba, kegiatan bazar, kegiatan posyandu, kegiatan karang taruna maupun kegiatan perayaan hari kemerdekaan dan perayaan keagamaan.

Menjawab permasalahan tersebut SDM dari perangkat desa perlu meningkatkan diri dengan berbagai macam cara baik melalui seminar, lokakarya, maupun pelatihan. Hasibuan (2010) mengatakan bahwa pelatihan adalah suatu usaha meningkatkan kemampuan teknis, teoritis, konseptual, dan moral 
pegawai sesuai kebutuhan pekerjaan atau jabatan melalui pelatihan. Mangkunegara (2011) menyatakan pelatihan merupakan suatu proses pendidikan jangka pendek yang mempergunakan prosedur sistematis dan terorganisir dimana pegawai non manajerial mempelajari pengetahuan dan keterampilan teknis dalam tujuan terbatas.

Pelatihan sering dianggap sebagai aktivitas yang paling umum dan para pimpinan mendukung adanya pelatihan karena melalui pelatihan, para pekerja akan menjadi lebih trampil dan karenanya akan lebih produktif, Menurut Rivai (2010) pelatihan meruapakan bagian pendidikan yang menyangkut proses belajar untuk memperoleh dan meningkatkan keterampilan di luar sistem pendidikan yang berlaku dalam relative singkat dengan metode yang mengutamakan praktik daripada teori. Hal ini juga diungkapkan oleh Caple dalam Priansa (2014) yang menyatakan bahwa pelatihan merupakan upaya yang sistematis dan terencana untuk mengubah atau mengembangkan pengetahuan/ keterampilan/ sikap melalui pengalaman belajar dalam rangka meningkatkan efektivitas kinerja kegiatan atau berbagai kegiatan.

Pelatihan untuk membuat desain grafis menjadi hal yang dirasa sangat perlu untuk menigkatkan kreatifitas dari perangat desa maupun warga masyarakat yang ikut terlibat dalam kegiatan secara Bersama-sama. Adapun tujuan umum dari pada pelatihan ini adalah:

a. Mengembangkan keahlian perangkat desa dan warga masyarakat sehingga pekerjaan dapat diselesaikan dengan lebih cepat dan lebih efektif.

b. Mengembangkan sikap, sehingga menimbulkan kerja sama dengan teman-teman pegawai dan pimpinan. Desa Ngembal memiliki permasalahan tentang kurangnya kreatifitas dari perangkat desa dan warga dalam membuat media untuk menyampaikan informasi yang berasal dari pemerintah pusat, dan informasi kegiatan desa yang telah dilakukan dalam kurun waktu tertentu, serta kesulitan dalam hal pendokumentasian kegiatan tersebut. Solusi yang ditawarkan adalah memberikan Pelatihan pembuatan Fotonovela Untuk Warga Desa Ngembal Kec. Wajak Kab. Malang.

\section{METODE}

Metode yang untuk menyelesaikan masalah mitra adalah pendampingan selama pelatihan pembuatan desain grafis dan fotonovela dengan menggunakan Corel Draw. Menurut Widiyanto (2006) definisi dari Corel draw adalah editor grafik vector yang dibuat oleh corel, Corel sendiri adalah sebuah perusahaan perangkat lunak yang bermarkas di Ottawa, Kanada. Versi terakhirnya versi 15 yang dinamai X5 dirilis pada tanggal 23 februari 2008. Corel draw pada awalnya dikembangkan untuk dijalankan pada Sistem Operasi Windows 2000 dan yang lebih baru. Corel Draw sendiri adalah sebuah program komputer untuk melakukan editing pada garis vector. Karena kegunaan Corel Draw adalah sebagai alat untuk pengolahan gambar, maka program ini sering digunakan untuk menyelesaikan pekerjaan di bidang publikasi atau percetakan maupun bidang yang lain yang butuh proses visualisasi. 
Adapun langkah-langkah praktis yang dilaksanakan adalah sebagai berikut :

a. Pendampingan kepada pengurus desa dan warga untuk melakukan kegiatan pelatihan yang sudah ditentukan. Pendampingan ini dimaksudkan untuk meningkatkan kualitas kegiatan Sumber Daya Manusia di Desa Ngembal.

b. Workshop terkait pembuatan fotonovela kegiatan warga. Dengan dilaksanakan workshop ini diharapkan pengurus desa dan warga yang mengikuti pelatihan memahami tentang langkah-langkah pembuatan media informasi dan fotonovela kegiatan warga. Dalam workshop ini, diajarkan bagaimana menggunakan software sebagai alat untuk mendesain dan membuat media informasi fotonovela. Peserta diajarkan secara bertahap dimulai dengan pemahaman terhadap tools dan fungsifungsinya, kemudian diberikan contoh bagaimana medesain, dan membuat serta mengaplikasikan desain sederhana hingga ke desain yang lebih komplek dan detail.

c. Pelatihan ini dilakukan hingga menghasilakan karya individu dan bersama/ kelompok, yang nantinya hasil karya tersebut akan dicetak dan dibagikan kepada warga serta dijadikan laporan kegiatan desa secara berkala.

Adapun ringkasan dari permasalahan dan solusi yang diberikan dapat dilihat pada Tabel 1 sebagai berikut:

\section{Tabel 1. Permasalahan, Solusi dan Metode Pemecahan Masalah}

\begin{tabular}{|l|l|l|l|}
\hline No & Permasalahan Mitra & Solusi & Metode \\
\hline 1 & $\begin{array}{l}\text { Warga kesulitan dalam } \\
\text { mendapatkan informasi seputar } \\
\text { program-program dari pemerintah, } \\
\text { dan kegiatan warga yang telah } \\
\text { dilakukan. }\end{array}$ & $\begin{array}{l}\text { Pelatihan mendesain objek } \\
\text { informasi dengan menggunakan } \\
\text { Corel Draw. }\end{array}$ & $\begin{array}{l}\text { Presentasi, Praktek } \\
\text { Langsung, } \\
\text { Diskusi }\end{array}$ \\
\hline 2 & $\begin{array}{l}\text { Informasi yang disajikan kurang } \\
\text { menarik dan tidak semua orang } \\
\text { bisa memahami maksud dari } \\
\text { informasi yang ada. }\end{array}$ & $\begin{array}{l}\text { Pelatihan membuat desain dengan } \\
\text { menggunakan kalimat yang lebih } \\
\text { sederhana dan menyajikannya } \\
\text { dengan lebih menarik. }\end{array}$ & $\begin{array}{l}\text { Presentasi, Praktek } \\
\text { Langsung, } \\
\text { Diskusi }\end{array}$ \\
\hline 3 & $\begin{array}{l}\text { Warga kurang mendapatkan } \\
\text { informasi tentang hasil kegiatan } \\
\text { yang telah dilakukan }\end{array}$ & $\begin{array}{l}\text { Pembuatan desain yang lebih } \\
\text { atraktif dengan menambahkan } \\
\text { beberapa objek gambar yang } \\
\text { sesuai dengan topik informasi. }\end{array}$ & $\begin{array}{l}\text { Presentasi, Praktek } \\
\text { Langsung, } \\
\text { Diskusi }\end{array}$ \\
\hline
\end{tabular}

\section{Aktivitas dan jadwal Kegiatan}

Pelatihan yang dilaksanakan selama 4 hari di Desa Ngembal yang dihadiri oleh 30 orang peserta yang terbagi menjadi 2 tahap, yaitu tahap pertama dimulai pagi pukul 08.00 - 12.00 dan tahap kedua dimulai pada siang hari pukul 13.00-16.00. Pelatihan ini dimulai dengan pengenalan software Corel Draw hingga membuat objek untuk penyampaian informasi.

Pengabdian kepada masyarakat ini dilaksanakan pada Bulan Mei. Adapun tempat pelaksanaannya dilakukan di Kantor Desa Ngembal. Sedangkan materi yang akan disampaikan pada pelatihan ini adalah 
mendesain media informasi dan membuat fotonovela dengan menggunakan software Corel Draw. Adapun jadwal pelaksanan dan rincian materi dapat dilihat pada Tabel 3.2.

Tabel 2. Jadwal Pelaksanaan dan Materi Pelatihan

\begin{tabular}{|c|l|l|l|l|l|}
\hline \multirow{2}{*}{ No } & \multirow{2}{*}{ Materi } & \multicolumn{4}{|c|}{ Pertemuan } \\
\cline { 5 - 6 } & & $\mathbf{1}$ & $\mathbf{2}$ & $\mathbf{3}$ & $\mathbf{4}$ \\
\hline A & Corel Draw & & & & \\
\hline 1 & Pengertian dan Pengenalan Corel Draw & & & & \\
\hline 2 & Pembuatan layout fotonovela & & & & \\
\hline 3 & $\begin{array}{c}\text { Menggambar sesuai tema dan informasi } \\
\text { kegiatan }\end{array}$ & & & & \\
\hline B & Presentasi Hasil & & & & \\
\hline 1 & Peserta menampilkan hasil karyanya & & & & \\
\hline
\end{tabular}

\section{HASIL}

Ketercapaian program pendampingan SDM pengurus dan warga Desa Ngembal Kecamatan Wajak, Kabupten Malang dapat dilihat dari antusias peserta baik pengurus maupun warga desa. Kehadiran pengurus MGMP dalam kegiatan ini 85\%, yaitu dari 10 pengurus desa dan 20 warga desa yang telah diseleksi oleh desa, yang rata2 selalu hadir dalam tiap sesi acara.

Kegiatan pendampingan dalam pelatihan ini tentu saja untuk memudahkan peserta untuk memahami dan membuat desain media informasi agar dalam setiap kegiatan informasi dapat tersampaikan dengan baik dan dapat terdokumentasi dengan baik.

Adapun beberapa hasil yang dicapai pada kegiatan ini adalah sebagai berikut:

a. Peningkatan pemahaman dan ketrampilan SDM desa ditujukkan dengan kreatifitas para peserta dalam membuat desain media. Salah satu contoh desain yang dihasilkan:

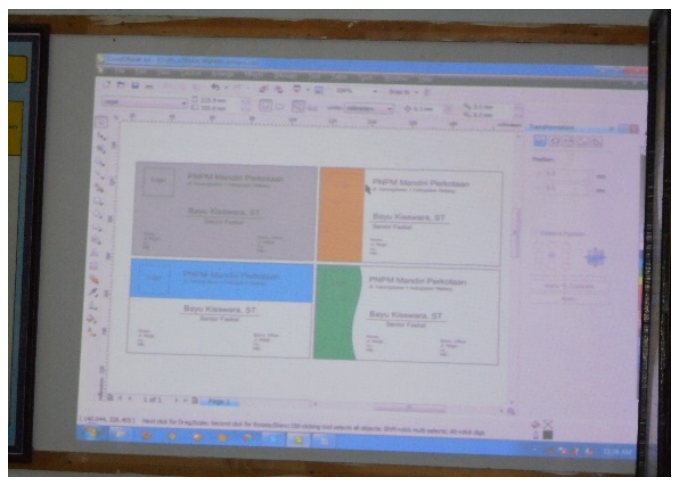

Gambar 1. Desain kartu anggota

Gambar 1 merupakan contoh latihan dasar desain dengan Software Corel Draw yaitu membuat kartu anggota atau kartu nama. 

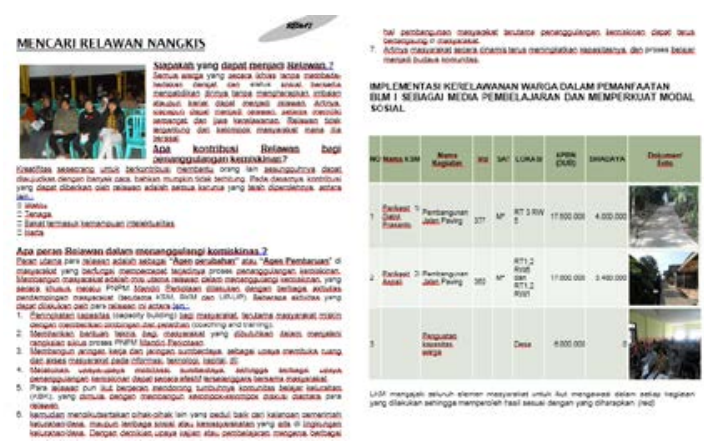

Gambar 2. Desain Buletin Kegiatan

Gambar 2 merupakan contoh latihan desain dengan materi lebih komplek berupa brosur dan pamflet.

b. Workshop pembuatan fotonovela kegiatan desa telah menghasilan beberapa desain yang cukup menarik, pada gambar 3 dan gambar 2 akan bisa dilihat contoh hasil desain dalam pelatihan

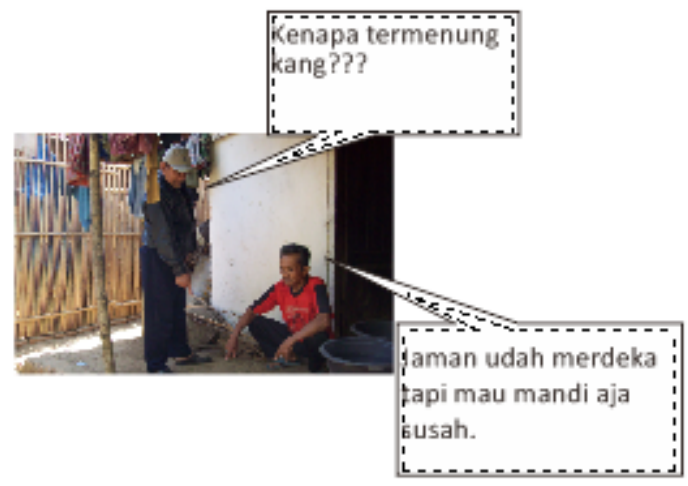

Gambar 3. Desain narasi Fotonovela

Gambar 3 merupakan contoh desain gambar dan cerita untuk membuat fotonovela.

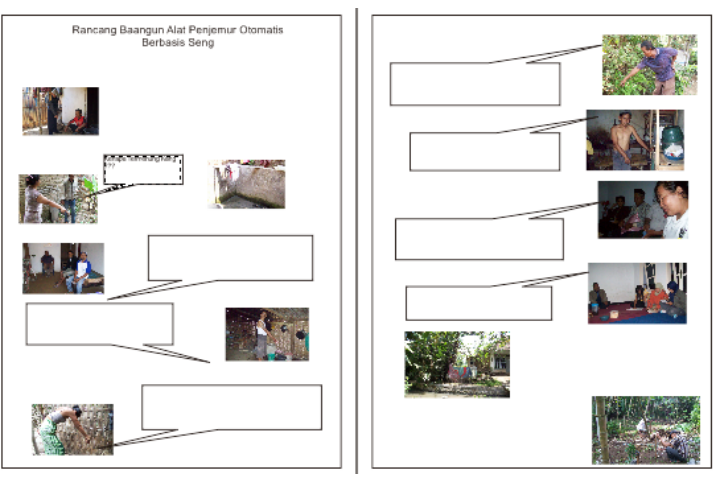

Gambar 4. Desain Fotonovela Kegiatan warga

Gambar 4 merupakan contoh desain gambar dan cerita yang lebih komplek untuk membuat fotonovela. Fotonovela ini dipergunakan untuk menceritakan kegiatan warga yang disampaikan dalam bentuk lebih menarik dengan foto dan narasi cerita. 
Berikut ini beberapa foto aktifitas pada saat pelatihan.

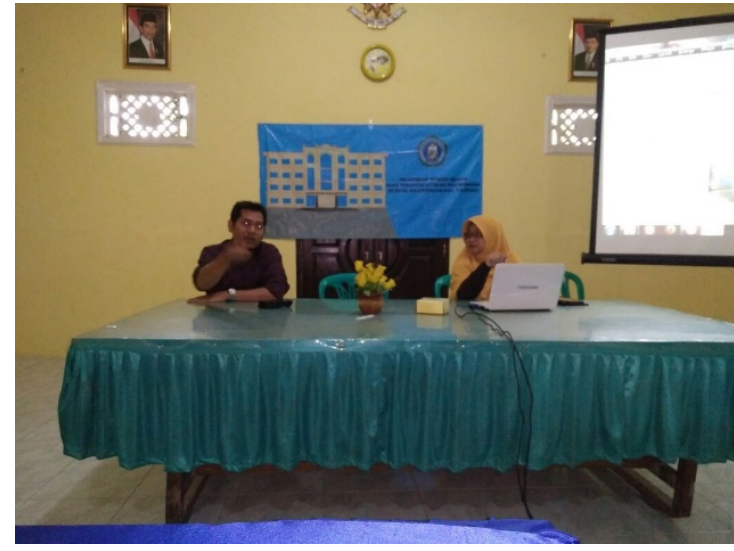

Gambar 5. Sesi ke-1 Pengarahan Pelatihan

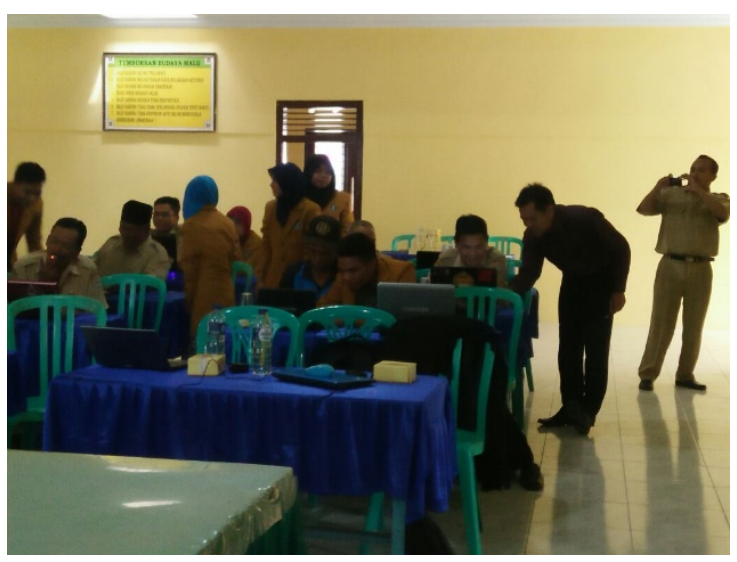

Gambar 6. Sesi ke 2 pelatihan Desain

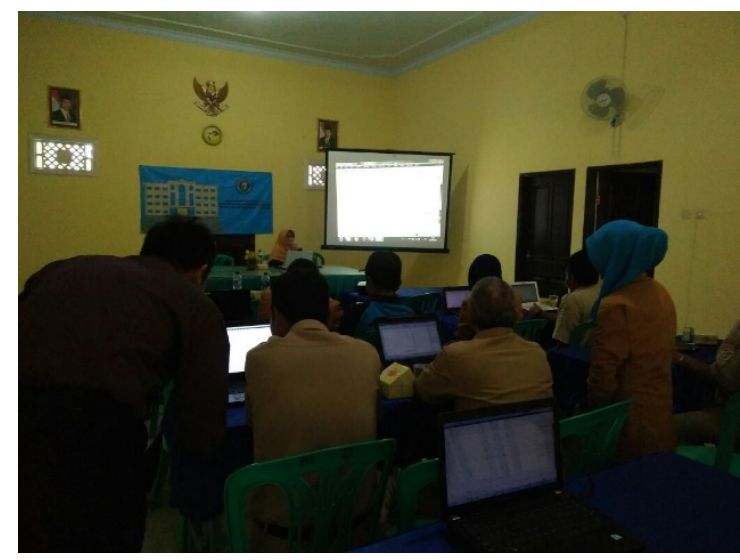

Gambar 7. Lanjutan Pelatihan Desain

\section{SIMPULAN}

Kegiatan Pengabdian Masyarakat pada pendampingan pengurus desa dan warga desa Ngembal, Kecamatan Wajak, Kabupaten Malang, telah sukses dilaksanakan dan mendapat respon yang positif dari para peserta. Pelatihan serupa juga pernah dilakukan oleh (Agustina, 2017), yang menyatakan bahwa Pelatihan dapat meningkatkan SDM peserta. Program pendampingan pelatihan ini menghasilkan beberapa contoh desain karya warga dan buletin fotonovela kegiatan warga yang saat ini menjadi dokumentasi dan di simpan di Kantor Desa Ngembal.

\section{DAFTAR PUSTAKA}

A. Anwar Prabu Mangkunegara, 2011. Manajemen Sumber Daya Manusia. Bandung: PT. Remaja Rosdakarya. 
Agustina, R, 2017, “Pelatihan Desain Grafis untuk Perangkat Desa dalam Rangka Peningkatan SDM di Desa Ngawonggo Kecamatan Tajinan Kab. Malang,” Jurnal Pengabdian Kepada Masyarakat 2, No. 1.

Hasibuan, Malayu S. P. 2010. Manajemen Sumber Daya Manusia. Jakarta. PT Bumi Aksara

Priansa, Donni Juni. 2014. Perencanaan dan Pengembangan Sumber Daya Manusia. Bandung: Alfabeta.

Rivai, Veithzal. 2011. Corporate Performance Management dari Teori Ke Praktek. Jakarta: Raja Grafindo Persada.

Widiyanto, Rahmad.2006.Teknik Profesional CorelDraw X3.Jakarta: PT.Elex Media Komputindo. 